\title{
PERANCANGAN SISTEM INFORMASI MANAJEMEN SKRIPSI MENGGUNAKAN BUSINESS SYSTEM PLANNING
}

\author{
Ruuhwan $^{1}$, Randi Rizal ${ }^{2}$, Aso Sudiarjo ${ }^{3}$ \\ ${ }^{1,2,3}$ Teknik Informatika, Universitas Perjuangan Tasikmalaya \\ Jl. Pembela Tanah Air(PETA) No. 177 Kota Tasikmalaya \\ 1uuhwan@unper.ac.id, $\underline{2}$ randirizal@unper.ac.id, ${ }^{3}$ asosudiarjo@unper.ac.id
}

\begin{abstract}
ABSTRAK
Sistem informasi pada suatu organisasi menjadi sangat penting untuk guna mengolah data dengan cepat untuk pengguna. Hal yang perlu dilakukan untuk pertama kali dalam membuat sistem informasi adalah membuat perencanaan. Metodologi yang digunakan untuk perencanaan sistem informasi adalah melakukan penyusunan rencana strategis dengan menggunakan Business System Planning (BSP). Metodologi ini bertujuan untuk upaya bagaimana sistem informasi harus terstruktur, terpadu, dan dilaksanakan oleh organisasi dalam jangka waktu lama. Universitas Perjuangan adalah salah satu universitas di Tasikmalaya. Manajemen pendaftaran dan pengelolaan skripsi di Universitas Perjuangan masih dilakukan secara manual. Selain itu tidak adanya sistem informasi untuk melihat kuota calon dosen pembimbing dan progres pengajuan tugas akhir menjadi kendala tersendiri dalam penentuan calon dosen pembimbing dan batas akhir proses pengerjaan skripsi. Dengan demikian diperlukan sebuah perencanaan untuk membangun sebuah sistem informasi manajemen skripsi yang nantinya akan bermanfaat untuk mengelola data skripsi dan memudahkan dalam hal pengajuan skripsi, penentuan pembimbing, penentuan penguji dan penentuan jadwal sidang. Langkah yang dilakukan dengan metodologi ini business system planning ini adalah mendefinisikan tujuan bisnis, proses bisnis, kelas data, arsitektur informasi dan integrasi.
\end{abstract}

Kata Kunci: Business System Planning, Skripsi

\begin{abstract}
Information systems in business organizations are very important related to the timeliness and correct supply of information needed by users. The first step to building an information system is to make a plan. One of the methodologies in making information system planning is the strategic plan arrangement which is carried out using Business System Planning (BSP). This methodology relates to the efforts of how the information system must be structured, integrated, and implemented by the organization in the long term. Universitas Perjuangan is one of the universities in Tasikmalaya. Registration management and thesis management at Universitas Perjuangan are still done manually. In addition, the absence of an information system to see the quota for prospective supervisors and the progress of submitting the final project is a separate obstacle in determining the prospective supervisor and the deadline for the thesis process. Thus, a plan is needed to build a thesis management information system which will later be useful for managing thesis data and making it easier for thesis submissions, determining supervisors, determining examiners and determining trial schedules. The steps taken with this business system planning methodology are defining business objectives, business processes, data classes, information architecture and integration.
\end{abstract}

Key Word: Business System Planning, Thesis

\section{PENDAHULUAN}

Setiap mahasiswa tingkat akhir yang akan menyelesaikan Pendidikan di suatu universitas diwajibkan untuk melakukan sebuah penelitian (Rusdi dkk., 2019). Skripsi merupakan sebuah proses pembelajaran terakhir yang wajib ditempuh mahasiswa untuk mendapatkan gelar Strata-1 (Prastyo \& Rosmawanti, 2016).

Salah satu tanggungjawab dosen di perguruan tinggi adalah membimbing mahasiswa yang akan melaksanakan skripsi sesuai dengan tri dharma perguruan tinggi yaitu : Pendidikan, Penelitian, dan Pengabdian (Patimah, 2018). Ada beberapa kendala yang terjadi pada perose pembimbingan mahasiswa tersebut yaitu batasan dosen untuk membimbing melebihi batas kuota yang telah ditetapkan, hal itu menyebabkan kualitas bimbingan yang dilakukan tidak optimal karena satu dosen membimbing terlalu banyak mahasiswa melebihi batasan yang ada dan ketidaksesuaian dengan kelompok keahlian yang diambil mahasiswa dengan dosen 
pembimbing dari kelompok keahlian yang sama (Dharmawan et al., 2019).

Proses pengajuan tugas akhir dan usulan dosen pembimbing di Universitas Perjuangan masih dilakukan secara manual sehingga menjadi kendala tersendiri yang mengharuskan mahasiswa datang ke kampus. Selain itu tidak adanya sistem informasi untuk melihat kuota calon dosen pembimbing dan progres pengajuan tugas akhir menjadi kendala tersendiri dalam penentuan calon dosen pembimbing dan batas akhir proses pengerjaan skripsi.

Sistem informasi pada suatu organisasi menjadi sangat penting terkait dengan kecepatan waktu dan kebenaran informasi yang diperlukan oleh pengguna (Aristi, 2014). Tahapan pertama yang harus dilakukan untuk membangun sistem informasi adalah membuat perencanaan. Salah satu metodologi dalam membuat perencanaan sistem informasi adalah susunan rencana strategis yang dilakukan dengan menggunakan Business System Planning (BSP) (Sirait et al., 2017). Metodologi ini berkaitan dengan upaya bagaimana sistem informasi harus terstruktur, terpadu, dan dilaksanakan oleh organisasi dalam jangka waktu lama (Arti, 2015).

Berdasarkan identifikasi masalah di atas, maka tujuan dari penelitian ini adalah: 1) Bagaimanakah proses penerapan Business System Planning untuk membangun Arsitektur Sistem Informasi Manajemen Skripsi di Universitas Perjuangan Kota Tasikmalaya? 2) Bagaimanakah proses perancangan Arsitektur Sistem Informasi Manajemen Skripsi dengan Business System Planning.?

\section{METODE PENELITIAN}

Metode deskriptif adalah metode yang digunakan dalam pengambilan data guna memberikan gambaran secara sistematis serta untuk mencari ada tidaknya suatu hal lain mengenai masalah yang diteliti dimana sumber data diperoleh dari:

1. Studi Literatur

Penelitian ini mengambil landasanlandasan teori dari berbagai jurnal ilmiah tentang arsitektur informasi, Business System Planning yang diambil maksimal 10 tahun yang lalu
2. Riset Lapangan

Riset yang dilakukan secara langsung ke untuk mendapatkan data-data yang diperlukan. Pengumpulan data dilakukan dengan cara:

a. Wawancara ( Interview)

Dalam hal ini penulis melakukan wawancara atau konsultasi secara langsung dengan beberapa pegawai di Universitas Perjuangan Tasikmalaya

b. Observasi

Meninjau secara langsung objek yang diteliti di Universitas Perjuangan Tasikmalaya

Business System Planning merupakan suatu pendekatan atau metodologi yang terstruktur. Pada tahun 1980-an, perusahaan IBM mengembangkan metodologi Business System Planning. Metodologi ini berkaitan dengan bagaimana proses pembuatan sistem informasi yang seharusnya distrukturkan, diintegrasikan dan diimplementasikan oleh organisasi dalam jangka panjang (Royanti, 2018).

Business System Planning adalah konsep dasar dalam perencanaan sistem informasi yang dibuat secara top-down menggunakan pelaksanaan secara bottom-up. (Ricec, 2019). Konsep ini dinyatakan dalam bentuk diagram seperti terlihat pada gambar di bawah ini.

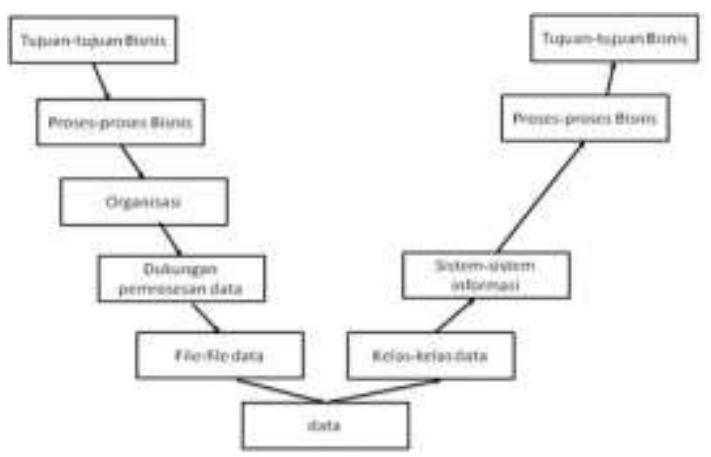

Gambar 1. Metode Business System Planning

Metode Business System Planning merupakan metode yang saling tehubung dengan cara bagaimana sistem informasi seharusnya distrukturkan, diintegrasikan, dan diimplementasikan oleh organisasi dalam jangka panjang (Musrini \& Supriatna, 2013). Adapun tahapan-tahapan yang digunakan dalam merancang sistem manajemen skripsi di Universitas Perjuangan Tasikmalaya adalah: 


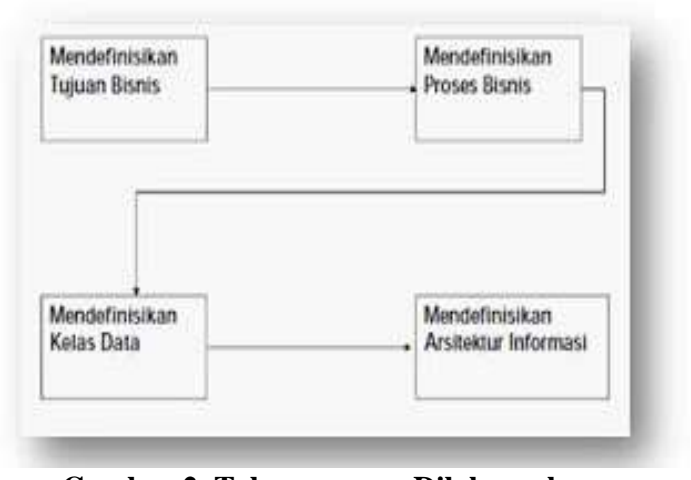

Gambar 2. Tahapan yang Dilaksanakan

Seperti yang terlihat gambar 2 bahwa business system planning memiliki tahapan sebagai berikut:

1. Mendefinisikan tujuan bisnis

Pada tahapan ini bisnis yang akan bergerak harus menentukan terlebih dahulu tujuan apa yang ingin dicapai termasuk juga target apa yang ingin dicapai dalam jangka waktu pendek maupun panjangnya. Dan menjamin kesepakatan di antara tingkatan eksekutif tentang kemena bisnis akan berjalan

2. Mendefinisikan proses bisnis

Pada tahapan ini baru menentukan stategi bisnis yang akan diterapkan beserta dengan alur proses yang ingin digunakan. Dan membuat landasan utama jangka panjang dukungan SI terhadap bisnis

3. Mendefinisikan kelas data

Lalu pada tahapan ini mendefinisikan permasalah dan membagi kelas-kelas permasalahan tersebut kedalam berbagai kelompok-kelompok dan dilakukan berdasarkan proses-proses yang di dukung

4. Mendefinisikan arsitektur informasi

Pada tahapan ini baru membangun semua konsep yang telah dirumuskan baik itu dari segi struktur organisasinya, desain system informasi dan departemen system informasinya. tujuan informasi jangka panjang, dari arsitektur Informasi modulmodul yang ada dapat diidentifikasin, dijadwal dan dibuat

\section{HASIL DAN PEMBAHASAN}

Untuk menggambarkan pemodelan tracer study yang akan dikembangkan di Universitas Perjuangan menggunakan IDEF yang dapat dilihat pada gambar di bawah ini:

1. Perancangan Sistem

Proses ini dilakukan untuk mendefinisikan kebutuhan arsitektur system dan arsitektur data. Kegiatan utama yang dilakukan dalam dalam merancang system informasi manajemen skripsi, yaitu:

1) Menentukan masukan data

2) Menentukan laporan

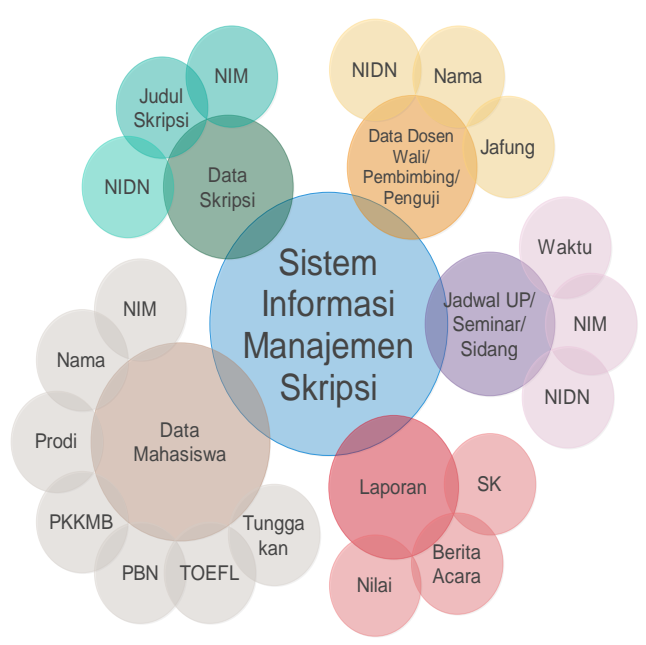

Gambar 3. Proses Bisnis Sistem Informasi Manajemen Skripsi

Gambar 3 merupakan proses bisnis sistem informasi manajemen skripsi yang terdiri dari penginputan data dengan rancangan interface untuk pengolahan data mahasiswa. pengolahan data skripsi, pengolahan data dosen wali/ dosen pembimbing/ dosen penguji, pengolahan data jadwal UP/ seminar/ sidang dan pengolahan data laporan.

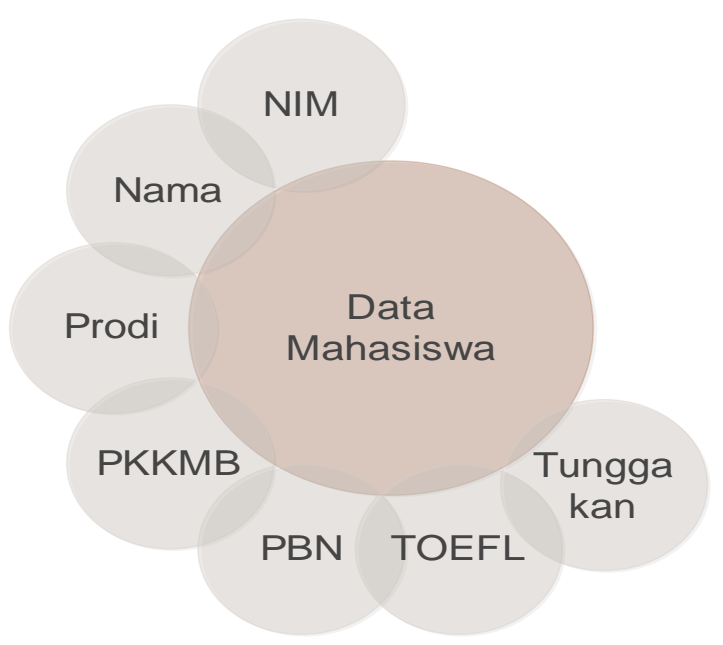

Gambar 4. Data Mahasiswa

Gambar 4 merupakan proses bisnis untuk rancangan interface dengan entitas NIM, Nama, Prodi, PKKMB, PBN, Toefl, Tunggakan. 


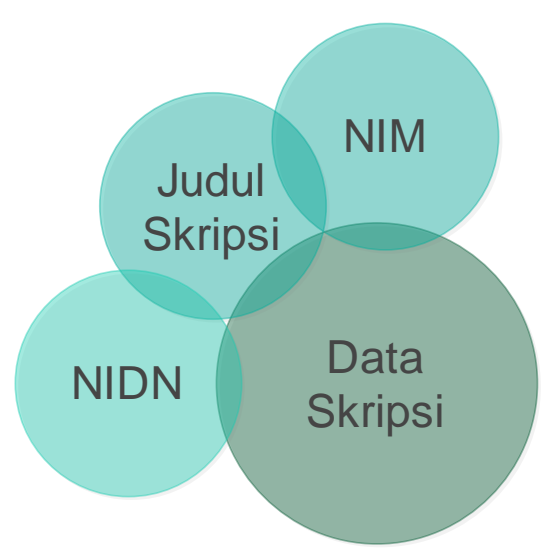

Gambar 5. Data Skripsi

Gambar 5 merupakan proses bisnis untuk rancangan interface dengan entitas NIM, Judul Skripsi, NIDN.

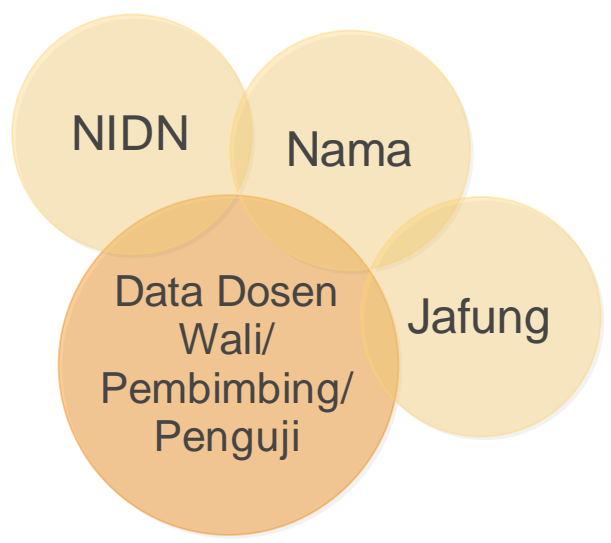

Gambar 6. Data Dosen Wali/ Pembimbing/ Penguji

Gambar 6 merupakan proses bisnis untuk rancangan interface dengan entitas NIDN, Nama, JaFung.

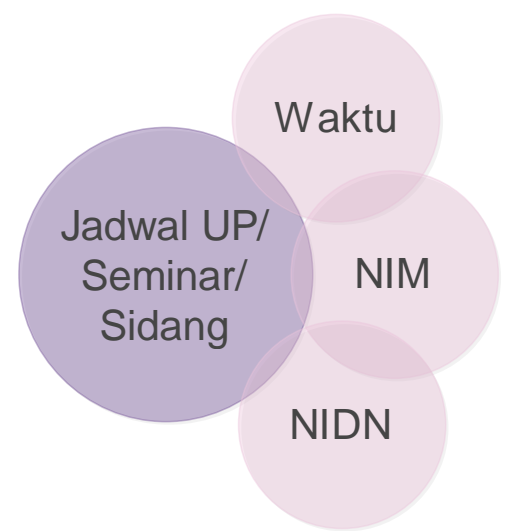

Gambar 7. Data Jadwal UP/ seminar/ sidang

Gambar 7 merupakan proses bisnis untuk rancangan interface dengan entitas Waktu, NIM, NIDN

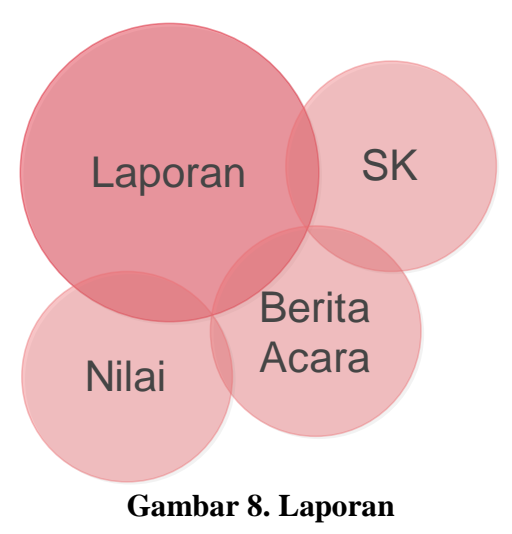

Gambar 8 merupakan proses bisnis untuk rancangan interface dengan entitas SK, Berita Acara, Nilai.

2. Perancangan Database

Entitas data sistem informasi manajemen skripsi adalah:

Tabel 1. Entitas Data

\begin{tabular}{|l|l|}
\hline \multicolumn{1}{|c|}{ Fungsi Bisnis } & \multicolumn{1}{|c|}{ Data Kelas } \\
\hline Data Mahasiswa & NIM \\
\cline { 2 - 2 } & Nama \\
\cline { 2 - 2 } & Program Studi \\
\cline { 2 - 2 } & PKKMB \\
\cline { 2 - 2 } & PBN \\
\cline { 2 - 2 } & TOEFL \\
\cline { 2 - 2 } & Tunggakan \\
\hline Data Skripsi & NIM \\
\cline { 2 - 2 } & Judul Skripsi \\
\cline { 2 - 2 } Pata Dosen Wali/ & NIDN \\
\cline { 2 - 2 } Pembimbing/ Penguji & Nama \\
\cline { 2 - 2 } & JaFung \\
\hline Jadwal UP/ Seminar/ & Waktu \\
\cline { 2 - 2 } Sidang & NIM \\
\cline { 2 - 2 } & NIDN \\
\hline
\end{tabular}

\section{SIMPULAN DAN SARAN}

Berdasarkan penelitian yang telah dilakukan, dapat diperoleh:

1. Perencanaan sistem informasi diperoleh dari komponen bisnis di Universitas Perjuangan untuk manajemen skripsi menggunakan BSP.

2. Aktivitas utama yang didapat adalah proses pemasukan data, penentuan dosen penguji serja penentuan jadwal dan proses yang dilaporkan.

Hal yang harus dilakukan selanjutnya adalah membuat sistem informasi manajemen skripsi di universitas perjuangan sehingga proses pengajuan skripsi menjadi lebih mudah. 


\section{DAFTAR PUSTAKA}

Aristi, G. (2014). Penerapan Business System Planning untuk Perencanaan Pembangunan Sistem informasi Akademik (Studi Kasus: Universitas Siliwangi). Jurnal Paradigma, 16(1), $25-32$.

Arti, N. (2015). Pemodelan Arsitektur Informasi Dengan Menggunakan Metode Business System Planning. Jurnal Ilmiah Informatika, 3(2), 5469.

Dharmawan, M., Indriati, R., \& Sucipto. (2019). Sistem Informasi Manajemen Tugas Akhir. Semnas Inotek, 3(1), 151-154.

Musrini, M., \& Supriatna, P. (2013). Implementasi Bussiness System Planning Untuk Pembuatan Arsitektur Informasi Studi Kasus UPT HKI. Konferensi Nasional Sistem Dan Informatika, 41-50.

Prastyo, A., \& Rosmawanti, N. (2016). Sistem Informasi Manajemen Tugas Akhir Berbasis Web. Jutisi, 5(2), 10951106.

Ricec. (2019). Perancangan Arsitektur Informasi PT. Yunia Yoga Farma Bandung Menngunakan Metode Business System Planning.

Royanti, E. (2018). Perancangan Arsitektur Informasi untuk Wisma Lansia Menggunakan Metode Business System Planning.

Sirait, T., Sipayung, E., \& Priska, K. (2017). Pemodelan Arsitektur Informasi Menggunakan Metode Business System Planning (Studi Kasus: SMP Negeri 7 Manado). Jurnal Telematika, 12(1), 83-88. 